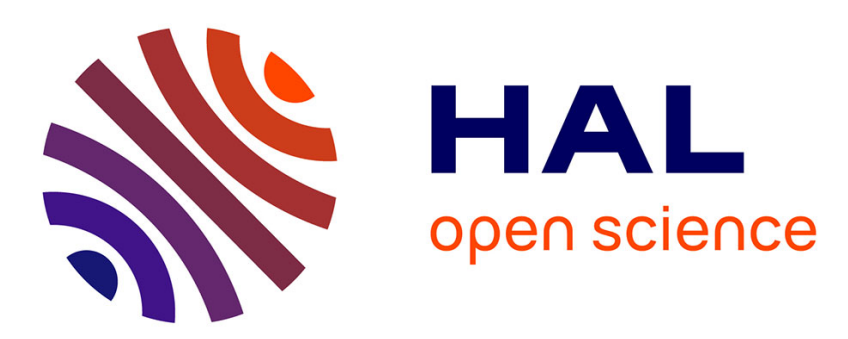

\title{
DEPTH MEASUREMENT OF THE PHASE CHANGE UNDER PULSED RUBY LASER ANNEALING
}

\author{
M. Toulemonde, R. Heddache, F. Nielsen, P. Siffert
}

\section{To cite this version:}

M. Toulemonde, R. Heddache, F. Nielsen, P. Siffert. DEPTH MEASUREMENT OF THE PHASE CHANGE UNDER PULSED RUBY LASER ANNEALING. Laser-Solid Interactions and Transient Thermal processing of Materials, 1983, Strasbourg, France. pp.C5-83-C5-86, 10.1051/jphyscol:1983513 . jpa-00223093

\section{HAL Id: jpa-00223093 https://hal.science/jpa-00223093}

Submitted on 1 Jan 1983

HAL is a multi-disciplinary open access archive for the deposit and dissemination of scientific research documents, whether they are published or not. The documents may come from teaching and research institutions in France or abroad, or from public or private research centers.
L'archive ouverte pluridisciplinaire HAL, est destinée au dépôt et à la diffusion de documents scientifiques de niveau recherche, publiés ou non, émanant des établissements d'enseignement et de recherche français ou étrangers, des laboratoires publics ou privés. 


\title{
DEPTH MEASUREMENT OF THE PHASE CHANGE UNDER PULSED RUBY LASER
}

\section{ANNEALING}

\author{
M. Toulemonde ${ }^{+}$, R. Heddache, F. Nielsen ${ }^{++}$and P. Siffert \\ CRN, Groupe PHASE, 67037 Strasbourg Cedex, France
}

\begin{abstract}
Résumé - Une brève impulsion de lumière (20 ns), délivrée par un laser rubis induit un changement de phase à la surface d'un monocristal de silicium. Il est reportê une mesure directe de l'épaisseur sur laquelle s'effectue ce changement de phase. les résultats expérimentaux sont en excellent accord avec les valeurs déduites d'un modèle purement thermodynamique.
\end{abstract}

\begin{abstract}
Irradiation of crystalline silicon by pulsed ruby laser induces a surface phase change. A direct measurement of the maximum thickness phase change is reported. Successful comparison with a thermal model is done.
\end{abstract}

Pulsed laser annealing of semiconductors, especially of silicon has been widely used in recent years [1-4]. In particular large contreversy appeared to explain the fondamental mechanism of annealing procedure : plasma and thermal model coexisted [1-4]. The later seems to be accepted now and has been completely investigated [5-11] in order to determine quantitatively the measured regrowth velocity [12-14], duration of surface melting [15-20]; depth of the melt phase [7,21] and temperature reached $[22-25]$.

As it has been already mention [14] the depth of the melt phase depend on the energy absorbed in the solid rather than the impinging one. Therefore the depth of melting constitute a good test of validity of the theoretical models developped to described pulsed laser annealing since it involves espacially the precise knowledge of the reflectivity changes. So the object of this work will be to determine the maximum of the phase change depth and to compare with theoretical determinations.

\section{I - DEPTH MEASUREMENTS OF THE PHASE CHANGE}

A Q-switched ruby laser $(\lambda=0.693 \mathrm{um})$, operating in TEM mode with a $20 \pm 1 \mathrm{~ns}$ FWHi pulse duration, has been used at power densities ranging from 0.5 to $2 \mathrm{~J} / \mathrm{cm}^{2}$. This laser can be used in repetitive mode each 6 or $30 \mathrm{~s}$ with a beam spot size as large as $9 \mathrm{~mm}$. The mean spatial power density has been measured using an external aligned collimator, having an aperture variable from 1 to $9 \mathrm{~mm}$ in diameter, placed at $20 \mathrm{~cm}$ in front of the silicon samples. With the same incident power density it has been found that by changing the aperture from 2 to $5 \mathrm{~mm}$ in diameter the mean spatial power density was kept constant within $15 \%$. Moreover with a fixed aperture the collimator can be moved horizontally and vertically. A scan of the spot with a $2 \mathrm{~mm}$ aperture has revealed a variation of the power density of $15 \%$ in a range of $2.5 \mathrm{~mm}$ around the center of the laser spot. Then the used aperture was $5 \mathrm{~mm}$.

To determine the depth of the phase change, dopants have been implanted into silicon and their profile has been determined by nuclear techniques after multiple laser shots. Indeed, several experiments $[26,27]$ have shown that the diffusion of dopants during the phase change is large when compared to diffusion in solid phase. Therefore by using repetitive pulses, the implanted dopant distribution reaches a maximum depth which corresponds to the tkickness of the phase change. Calculations following the procedure described by WHITE etal [26] has been performed in order to

\footnotetext{
+Present address : CIRIL, B.P. 5133, 14040 Caen Cedex, France.

Present address : Institute of Physics, Univ. of Aarhus, DK-8000 Aarhus, Denmark.
} 


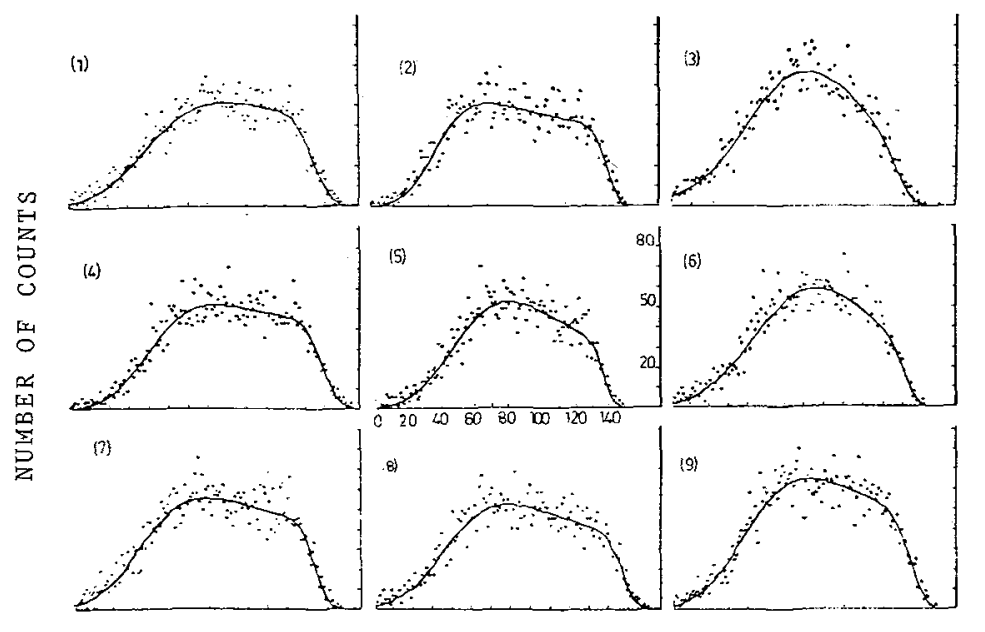

Fig. 1 -

Arsenic scan profiling. The incident energy of the laser was 1.2 $\mathrm{J} / \mathrm{cm} 2$. The line is a fit to determine the width of the peak which corresponds to the thickness.

C $\quad H \quad A \quad N \quad N \quad E \quad L$

calculate the number of shots necessary to induce the diffusion of a significant number of dopants towards the maximum depth of the phase change. Boron and Arsenic has been used as dopants : a dose of 4 x $1016 \mathrm{~B} / \mathrm{cm}^{2}$ of $20 \mathrm{KeV}$ and $3 \times 1016 \mathrm{As} / \mathrm{cm}^{2}$ of 20 and $120 \mathrm{KeV}$ were implanted in silicon wafers. These dopants have been used since the effective segregation coefficient is equal or near to 1 under laser annealing [26,27]. After a first shot, ellipsometry and backscattering measurements show that the wafers have refound the crystal quality and that diffusion of the dopants is largely less than the redistribution of the dopants after 30 to 50 laser shots. So the first shot on amorphous layer would not affect the depth measurement of phase change in a crystal. The boron profile has been determined by the use of the ( $p, a)$ reaction at $163 \mathrm{KeV}$ resonnance [28]. Rutherford backscattering was used to profile the As diffusion. As the diameter of the probe beam (proton and crespectively) was $2 \mathrm{~mm}$ the laser spot was scanned. For each step of the scanning a thickness of diffusion was determined and a mean value of the depth phase change is extracted from all measurements done one the same spot. An exemple of scan is shown on fig. 1 and the mean results are summurized on table 1. It can be observed also that the measurement performed at the center of the spot give the same depth value that the one extracted from the scanning average. In order to confirm these results, an homogenizer has been constructed [29] and used. The results obtained under the later conditions are also given in table $\uparrow$.

In order to investigate the influence of the initial conditions (temperature) during illumination, experiments have been performed on samples preheated to $650 \mathrm{~K}$. Typica1 results are given on figure 2 .

T A.B LE I - Depth values of the phase change -

\begin{tabular}{|c|c|c|c|c|c|c|}
\hline $\begin{array}{l}\text { Power density } \\
\mathrm{J} / \mathrm{cm}^{2}\end{array}$ & dopants & $\begin{array}{l}\text { mean value } \\
\text { ( nn) }\end{array}$ & $\begin{array}{c}\text { center value } \\
\text { (nti) }\end{array}$ & $\begin{array}{c}\text { with homogenizer } \\
\text { (nm) }\end{array}$ & $\begin{array}{l}\text { adopted } \\
\text { value } \\
\text { (nm) }\end{array}$ & $\begin{array}{c}\text { thearetical } \\
\text { value } \\
\text { (nm) }\end{array}$ \\
\hline 1.07 & As & $175+20$ & $165 \pm 30$ & & $175+20$ & 175 \\
\hline 1.1 & As & & & $180 \pm 30$ & $180 \pm 30$ & 185 \\
\hline 1.2 & As & $280 \pm 30$ & $270+40$ & & $280 \pm 30$ & 240 \\
\hline 1.3 & As & $275 \pm 30$ & $290+40$ & $240 \pm 30$ & $260 \pm 20$ & 295 \\
\hline 1.41 & As & $430+40$ & $435 \pm 45$ & $305+30$ & $360+40$ & 355 \\
\hline
\end{tabular}


TABLE I I - Values of the parameters introduced in the thermal model -

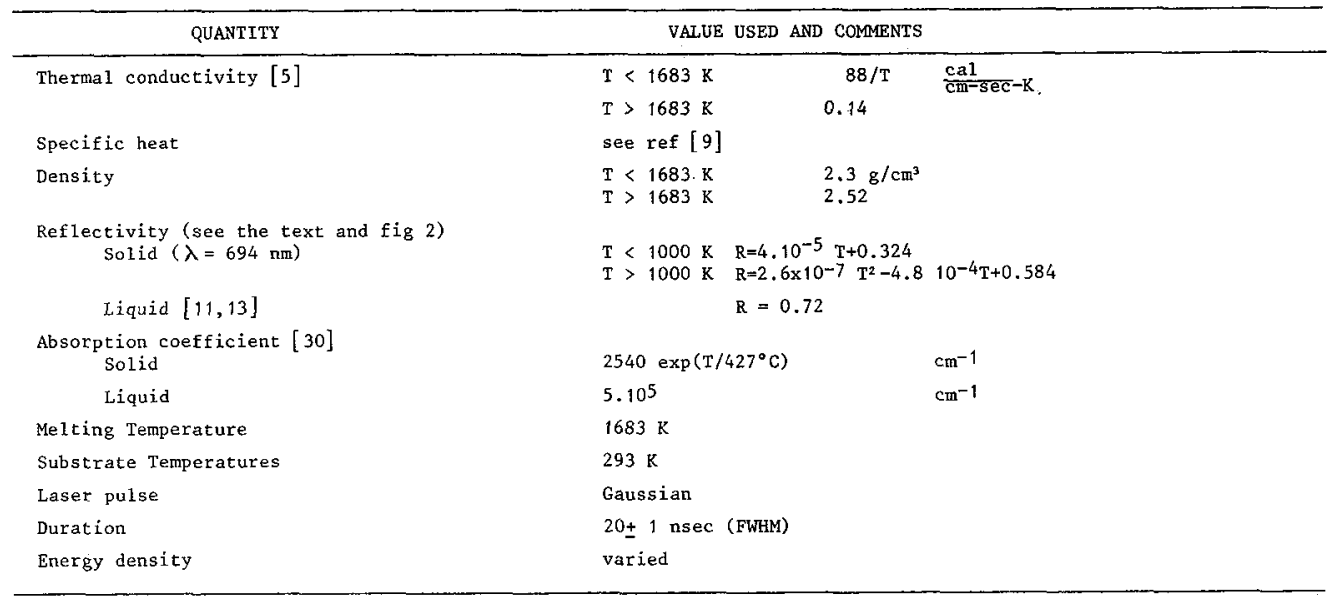

\section{II - COMPARAISON WITH THE THERMAL MODEL}

The thermal model have been described previously [5]. That consists to solve numerically the heat flow equation since al1 the parameters are temperature dependant (table 2). As it is said in the introduction the determination of the absorbed energy is of important. So the determination of the value of the reflectivity versus the temperature was determined by an average of all recents results [30-33]. With that value (table 2) it has been calculated that at a power density of $0.50 \mathrm{~J} / \mathrm{cm}^{2}$, the mean absorbed energy is $61 \%$ of the incident energy, in very good agreement with the mean experimental determination [34]. The calculated melt depth has been reported on fig. 2 and it can be observed an excellent agreement whatever is the substrate temperature. Moreover a calculation have been done in order to compare with the results of Bell [7] and the agreement is good.

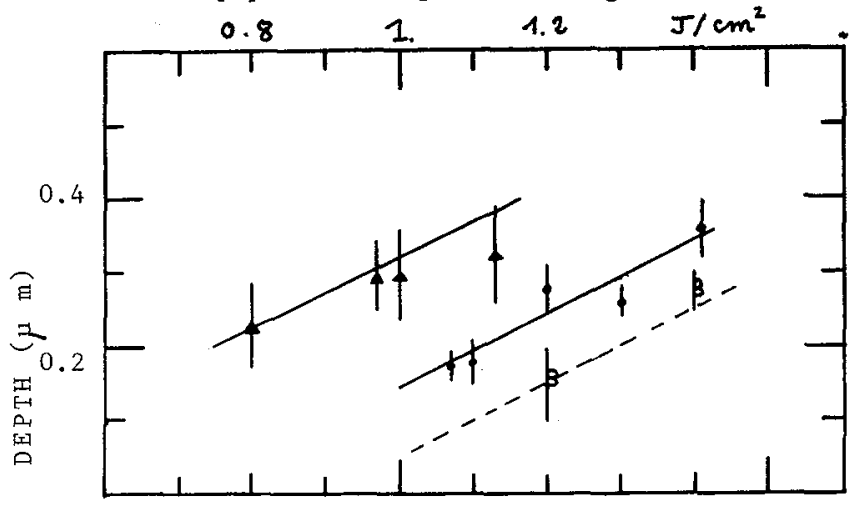

POWER DENSTTY

ig. 2 - Depth versus power density. Ainitial temperature $650 \mathrm{~K}$

- Room Temperature. B results are from ref.[7]. The straight lines are the model calculation. 


\section{III - CONCLUSION}

In this paper it is shown that the thermal model is able to predict the maximum melt depth induced by a pulsed ruby laser whatever is the temperature substrate. Furthermore the good agreement obtained with experimental results indicates that the evolution of reflection coefficient with tempexature is now correctly described no conclusion can be given concerning the evolution of thermal conductivity since a variation of $50 \%$ leads to a change of only $10 \%$ of the melt depth [9].

\section{- ZEFERENCES -}

1 . Laser-solid interactions and Leser processing, ed, S.D.Ferris, H.J.Leamy and J.M.Poate, (AIP, New York 1979)

2 . Laser and electron Beam processing of Materials, ed. C.W.White and P.J.Peercy (Academic, New York 1980)

3 . Laser and Electron Beam Solid Interactions and Materials Processing, ed. J.F.Gibbons, L.D.Hess, T.W.Sigmon (North Holland, New York 1981)

4 . Laser and Electron Beam Interactions with Solids, ed.B.R.Appleton and G.K.Celler (North hol land, New York 1982)

5 . R.O.Bell, M.Toulemonde and Siffert, Appl. Phys. 19 (1979) 313.

6 . C.M.Surko, A.L.Simons, D.H.Auston, I.A.Golovchenko, R.E.Slusher and T.N.C.Venkatesan, Appl. Phys, Lett. 34 (1979) 635.

7 . A.E.BeIl, RCA Review 40 (1979) 295.

8 . J.R.Meyer, M.R.Kruer and F.J.Barto1i, J. App1. Phys. 51 (1980) 5513.

9 . R.F.Wood and G.E.Giles, Phys. Rev. B23 (1981) 2923.

10. P.Baeri, S.U.Campisano, G.Foti and E.Rimini, J. Appl. Phys. 50 (1979) 788.

11 . J.S.Schultz and R.J.Collins, Appl. Phys, Lett. 34 (1979) 84.

12 . G.J.Galvin, M.O.Thompson, J.W.Mayer, R.B.Hamond, N.Paulter and P.S.Peercy, Phys. Rev. Lett. 48 (1982) 33.

13. P.S.Peercy, G.J.Galvin,M.0.Thompson, J.W.Mayer and R.B.Hammond, Physicá 116 B (1983) 558.

14. M.0.Thompson, J.W.Mayer, A.G.Cullis, H.C.Webber, N.G.Chew, J.M.Poate and D.C.Jacobson, Phys, Rev. Lett. 50 (1983) 896.

15. K.Murakami, K.Gano, M.Kawabe, S.Namba and Y.Aoyagi,Jpn. J. AppL. Phys. 18 (1972) 2311.

16 . D.K.Auston, C.M.Surko, T.N.C.Venkatesan, R.E.SIusher and J.A.Colovchento, AppI. Phys. Lett. 33 (1978) 437.

17 . Y.S.Liu and K.L.Wang, Appl. Phys. Lett. 34 (1979) 363.

18 . M.C.Lee, H.W.Lo, A.Aydin1i and A.Compaan, App1. Phys. Lett. 38 (1981) 499.

19 . D.H.Lowndes, Phys. Rev. Lett. 48 (1982) 267.

20 . D.H.Lowndes, G.E.Jellison and R.F.Wood, Phys. Rev. B26 (1982) 6747.

21 . J.Narayan, App1. Phys. Lett. 34 (1979) 312.

22 . H.W.Lo and A.Campaan, Phys. Rev. Lett. 44 (1980) 1604

23 . H.W.Lo and A.Campaan, Appl. Phys. Letr. 38 (1981) 179.

24 . G.E.Jellison, D.H.Lowndes and R.F.Wood (see ref. 4)

25 . B.Stritzker, A.Pospieszczyk and J.A.Tagle, Phys. Rev. Lett. 47 (1981) 356.

26 . C.W.White, S.R.Wilson and B.R.Appleton J.Appl. Phys. 51 (1980) 738.

27 . R.F.Wood, J.R.Kirkpatuck, G.E.Giles, Phys. Rev. 23B (1982) 55555.

28 . E. Ligeon and A.Bontemps, J. of Rad. Chem. 12 (1972) 335.

29. A.G.Cullis, H.C.Weber and P.Bailley, J. Phys E : Sci. inst, 12 (1969) 68.

30. G.E.Jellison and F.A.Modine, Appl. Phys. Lett. 41 (1982) 180, and subtuitted to Phys. Rev. B.

31. F.G: Allen, J. Appl. Phys. 28 (1957) 1510.

32 . Y.J.Van der Meulen and N.G.Hien, J. Opt. Soc. An. 64 (1964) 804.

33 . M.O.Lampert, J.M.Koebel and P.Siffert, J. Appl. Phys. 52 (1981) 4975.

¿34 . P.S.Peercy and W.R.Wrampler, Appl. Phys. Lett. 40 (1982) 9. 